\title{
ECONOMIC SANCTIONS AND THE DURATION OF CIVIL CONFLICTS
}

\author{
Abel Escribà-Folch \\ Institut Barcelona d'Estudis Internacionals
}

2008

\begin{abstract}
This article studies the impact of economic sanctions on the duration and outcome of intrastate conflicts. Sanctions are argued to foster the convergence of beliefs over parties' capacity, to reduce the utility of victory and to increase the costs of continuing fighting. Using a sample of 87 wars and new data on sanctions and sanction types, I show that sanctions and their duration are statistically associated with shorter intrastate conflicts. It is also shown that total economic embargoes are the most effectual type of coercive measure in these cases and that sanctions either imposed by international organizations or other actors have similar negative effects on war duration. In the second part of the article, we disaggregate the dependent variable and demonstrate that sanctions imposed by international institutions increase the likelihood of conflict resolution, whereas those sanctions not imposed by such institutions tend to increase the probability of a military victory. Besides, if the targeted state is a member of the international institution imposing sanctions, the effect of such coercion is even greater. Economic embargos are also proven to increase the likelihood of a military as well as a negotiated end, whereas international arms embargos reduce the likelihood of a military victory.
\end{abstract}




\section{Introduction}

Although economic sanctions are among the most commonly used instruments of international relations, their usefulness and efficacy are constantly under debate and, quite often, doubted (Pape, 1997, 1998; Nurnberger, 2003). Sanction episodes have been motivated by a multiplicity of factors, among which civil conflicts and political violence are among the most prominent. To cite some examples, sanctions have targeted countries experiencing civil war, such as Liberia, Yugoslavia, Sudan, Rwanda, Lebanon, Azerbaijan or Cambodia. Assessing whether these instruments of international relations have had any significant effect in bringing about war termination is especially relevant now that the use of sanctions has sharply increased since the 1990s.

The existing literature on civil war duration has already emphasized the important role that external actors may play in bringing conflict to an end or, conversely, lengthening it, although the existing evidence is still limited and contradictory in some cases. Sanctions constitute a rather specific method of intervention based on coercive measures imposed by one country, an international organization or a coalition of countries against another country - its government or any group within - in order to bring about a change in a specific policy or behaviour (Rennack and Shuey, 1998). The debate about sanctions revolves not only around their efficacy as a coercive measure, but also around whether some sanctions - unilateral versus multilateral, for example - are more successful than others (Askari et al., 2003). As the controversy continues, the number of sanctions imposed has sharply increased over the last decades, especially those imposed by the United Nations.

The aim of this paper is to analyze the effect of economic sanctions on the likelihood of civil war termination in order to aid our understanding of the usefulness of third-party interventions and their modalities. We also study the effect of different types of sanction and how they affect the type of war termination (i.e., military victory versus negotiated settlement). To do so, we use a large dataset including 87 intrastate conflicts occurring between 1959 and 1999. Our results show that international sanctions and their duration have a negative and significant effect on civil war length. Further refinements of both the main independent and dependent variables serve to show also that the most effective measure is a total economic embargo against the target country. Regarding multilateral sanctions, we show that sanctions imposed by multilateral international institutions increase the likelihood of a negotiated settlement, while those not 'covered' by such institutions lead to military victories. 
The paper is structured as follows. Section 2 briefly summarizes the literature on civil war duration and the variables often used to explain it. Section 3 theorizes about the potential effect of economic sanctions and their types on the durability of civil wars and the mode of conflict termination, paying attention to the mechanisms that may link both variables. In Section 4 we present the data used as well as the main methods. Section 5 reports and discusses the empirical results. Finally, Section 6 summarizes the main findings.

\section{Civil War Duration: A Review}

The growing literature studying the expected duration of civil wars basically bases its explanations fundamentally on the costs of war, forecast errors, actors' capabilities and polarization (Licklider, 1995), which can be affected or altered by a number of factors. Proceeding from a rebellion-as-business or a greed and feasibility view, one important part of this research concentrates on the impact that natural resources may have on both the onset and the duration of civil war (Ross, 2004). In this line, Collier et al. (2004) show that a decline in the prices of the primary commodities that a particular country exports tends to shorten conflict. Humphreys' (2005) results reveal that natural resources are actually associated with shorter intrastate wars because they increase the likelihood of military victory. Likewise, DeRouen and Sobek (2004) demonstrate that primary commodity exports increase the probability of a government victory or a settlement.

Collier (2000) even places the possibility of looting at the core of the rebels' motivations. Fearon (2004) empirically proves that it is especially the presence of contraband (of, for example, goods like gems, opium or cocaine) which allows the rebels to obtain the resources to sustain a long-running conflict. Disaggregating this latter possibility, Buhaug et al. (2005) find an important impact of alluvial diamonds and gemstones on conflict duration, but find that drugs exert no significant effect ${ }^{1}$.

Other structural variables have been proven to be associated with civil conflict length. Some researchers point to the potential polarizing effect of ethnic fractionalization (Humphreys, 2005; Montalvo and Reynal-Querol, 2007). It is argued that a high degree of fractionalization may hamper cooperation and cohesion on the rebel side (DeRouen and Sobek, 2004). Furthermore, Collier et al. (2004) and Elbadawi

\footnotetext{
${ }^{1}$ See also Buhaug et al. (2002).
} 
and Sambanis (2000) find a non-linear relationship between ethnic diversity and war duration. Other studies do not support this claim and find either no relationship or a marginal effect of ethnic diversity on war duration (Fearon, 2004).

The geographical characteristics of the country have also been alleged to matter. Thus, mountainous terrain, forest cover and the number of contiguous states are often cited as factors that enhance the ability of rebels to resist, and, therefore, should be expected to increase conflict duration. These variables are generally not found to be significant though, except in DeRouen and Sobek's (2004) work, where forest cover is shown to increase war duration, and the number of borders to reduce it. Buhaug et al. (2005) find that the location of the conflict exerts an important effect on conflict length.

Regarding external interventions, the available evidence is rather inconclusive. Third-party interventions predominantly rely on the manipulation of the costs associated with continued warfare. From this perspective, interventions may be directed toward assisting the government, supporting the rebellion or remaining neutral, and may take different forms. Nonetheless, those studies relying on Regan's $(2000,2002)$ data on third-party interventions do not agree on the sign of the effect of those interventions on expected conflict durations.

On the one hand, Collier et al. (2004) argue that economic interventions, whether pro-rebel or pro-government, are wholly insignificant, while only military interventions on the side of the rebels have an effect on shortening civil war. Against this, Buhaug et al. (2002) find that interventions on the government's side do lead to longer civil conflicts. According to Elbadawi and Sambanis (2000), interventions tend to reduce the cost of coordinating a rebellion, thereby making warfare last longer. After incorporating some refinements to the data, Regan (2002) reports that both economic and military interventions have a positive impact on intrastate war length. Nonetheless, he shows that biased interventions are associated with shorter expected durations than are neutral interventions ${ }^{2}$. Likewise, Balch-Lindsay and Enterline (2000) show that an equitable distribution of third-party interventions makes civil wars last much longer. Balch-Lindsay et al. (2008) revise the impact of third-party interventions by distinguishing the civil war outcomes. In doing so, they reveal that third-party intervention on one of the sides (government or opposition) reduce the time until that

\footnotetext{
${ }^{2}$ This is also the logic that pervades the theoretical literature on mediation. For instance, Kydd (2003) argues that the information provided by an unbiased mediator, unlike a biased one, will not be considered credible by the parties to a conflict.
} 
group achieves military victory but it makes a negotiated settlement more unlikely (see also Mason et al., 1999). This is consistent with Cunningham (2006) finding that multiple veto players are related to longer conflicts. In contrast, DeRouen and Sobek (2004) show that UN interventions increase the probability of conflict resolution concretely, of a truce and a treaty that put an end to violence. Furthermore, Doyle and Sambanis (2000) remark that multilateral enforcement operations are generally effective in reducing violence.

\section{Sanctions, Types of Sanctions and Conflict Resolution}

As remarked in the introduction, there is still no general agreement about the effectiveness of sanctions. The first comprehensive empirical study revealed a low success rate of imposed sanctions (Hufbauer et al., 1990; 2007) ${ }^{3}$. Later research tended to increase scepticism contending that sanctions basically do not work and that any policy effect observed is due to the use of force that frequently accompanies them (Pape, 1997, 1998). Further studies then moved to investigate what kind of sanctions were more effective, under what conditions could sanctions be expected to work, and the role and impact of sanction threats.

Concerning threats, it is argued that, as economic coercion is the result of strategic interaction (Tsebelis, 1990), sanctions that are likely to succeed will do so at the mere threat stage (Drezner, 2003a; Lacy and Niou, 2004). On the other hand, some conditions have been identified as to make sanctions more likely to succeed. At this respect, a number of variables have been empirically proven to matter: sender's perceptions of the salience of the issue (Ang and Peksen, 2007), the initial stability of the target and the cost to the target country (Dashti-Gibson et al., 1997), the political regime of the targeted nation (Nooruddin, 2002; Lektzian and Souva, 2007), and future conflict expectations (Drezner, 1998). Finally, scholars have also sought to measure and explain coercion effectiveness from the perspective of the type of measures applied or according to the senders' characteristics. Some studies suggest that international cooperation is neither a sufficient nor a necessary condition for the success of sanction episodes, basically due to enforcement difficulties (see, for instance, Drezner, 1999; Hufbauer et al., 1990; Kaempfer and Lowenberg, 1999), nor, it seems, is the involvement of a superpower (Davis and Engerman, 2003). In fact, Drezner (2000)

\footnotetext{
${ }^{3}$ See also Elliot (1998) for a discussion. The updated version of the book reports the same rate of success, about one third. See Hufbauer et al. (2007).
} 
reports empirical evidence that reveals that multilateral sanctions that lack the support of an international organization are significantly less successful than unilateral coercion, whereas those supported by an international organization are more effective than unilateral measures. Using a new dataset on sanction episodes ${ }^{4}$, Bapat and Morgan (2007) find that in fact multilateral sanctions are more effective than unilateral ones. And as for the targeted measures, it is generally thought that smart sanctions can be more efficient since they are intended to focus costs on specific groups within the targeted country. For instance, Dashti-Gibson et al. (1997) find that for those sanctions seeking to yield policy changes the imposition of financial sanctions is a key determinant of success. Others find evidence supporting comprehensive sanctions greater effectiveness (Cortright and Lopez, 2002), as they maximize economic and social impact on the target.

Economic sanctions constitute a concrete type of intervention based solely on coercive measures consisting on different types of intended economic damage with the aim of triggering a policy change in the target government or country (McGillivray and Stam, 2004). One of the main motivations of such measures is intrastate conflicts, human rights violations and violence, so an appropriate way to asses their success is to analyze whether sanctions have been of any help in shortening civil wars (and fostering conflict resolution) and to discern what type of sanctions is more effective in achieving such goal.

The studies of external interventions so far reviewed have not considered sanctions separately; rather, they use the term 'economic interventions', which may include aid, grants and restrictions. Thus, we know little about the specific impact of economic sanctions - if any - in some specific contexts like intrastate conflicts. So far, sanctions, interpreted as a type of costly signal from an external actor, have been shown to exert no significant impact on the probability of civil war onset (Thyne, 2006). Concerning duration, the existing evidence is only partial and based on an extremely limited number of cases (Strandow, 2006) ${ }^{5}$. On the other hand, the literature on sanctions' effectiveness has basically relied on ordinal assessments of the degree of success of sanction episodes, instead of making direct measurements or codifications of

\footnotetext{
${ }^{4}$ Most of the earlier analyses of sanction duration and effectiveness - and many current ones - are based on the Hufbauer, Schott and Elliot (1990) dataset.

5 Strandow analyses the impact of UN sanctions and threats in only two conflicts, Liberia and Ivory Coast.
} 
event occurrence ${ }^{6}$. And as Hufbauer et al. recognize, 'judgement plays an important role in assigning a single number to each element in the success equation' (1990: 41).

The potential impact of sanctions on war length could be approached from the existing third-party intervention perspective. Sanctions can be then just thought as constituting one particular form - economic - of external intervention into a civil conflict. Accordingly, such interventions may difficult reaching an agreement or a military victory by either entailing the involvement of a new veto player into the conflict which might reduce the range of acceptable agreements (Cunningham, 2006), by reducing the costs of rebellion coordination as Elbadawi and Sambanis (2000) contend, or by shifting the balance of parties' capabilities toward parity (Regan, 2002). Consequently, according to the existing evidence on external interventions reviewed in the previous section, economic sanctions would tend to lengthen the duration of civil wars; especially if we consider Regan's (2002) piece, which shows that economic interventions have a positive impact on intrastate war duration.

In contrast, sanctions can be argued to decrease civil war duration through various, more specific, mechanisms. Concretely, sanctions may operate in these cases by altering the parties' beliefs about the relative distribution of power, by reducing the amount of resources necessary to sustain warfare, or by affecting the structure of the incentives of the contending parts (for example, by reducing the expected payoff from victory).

On the one hand, as pointed out, sanctions can be placed in the context of the general uncertainty that wars involve. Hence, one set of arguments stresses that the parties in a conflict will continue to fight if they are uncertain about the actual distribution of power, which makes the demands of the other side generally unacceptable (Filson and Werner, 2002). In other words, forecast error - usually overoptimistic - on the part of one of the actors or both is related to longer wars (Elbadawi and Sambanis, 2000). This view coincides with the rebellion-as-mistake approach, which emphasizes the role of misperceptions about the military capability of each side as a key determinant of war persistence (Hirshleifer, 2001; Collier et al., 2004). Indeed, Cunningham et al. (2005) show that civil wars tend to last longer when rebel groups are in fact weaker vis-à-vis the government, especially, if those groups operate in the periphery or do not have a political wing. Under such conditions, a settlement is clearly

\footnotetext{
${ }^{6}$ Marinov's (2005) work on leadership stability is an exception.
} 
implausible. Then, conflict resolution is the result of convergence of the parties' beliefs over their relative power distribution, which sanctions can help to promote by influencing private information, as Strandow (2006) emphasizes. For instance, sanctions are argued to have been successful in stabilising the Liberian conflict. The arms embargo (imposed in 1992) made the acquisition and delivery of weapons more difficult and less predictable (Wallensteen et al., 2006). Charles Taylor even declared "we are hands-tied as a result of the arms embargo" (cited in Strandow, 2006: 11). A comprehensive peace agreement was reached in August 2003. The settlement prompted the resignation of former President Charles Taylor. The National Transitional Government of Liberia (NTGL) - which included both rebel and government groups took over two months later.

On the other hand, sanctions may shorten conflict through their impact on the beliefs over costs, on the incentives facing the parties involved to continue the fight and on the feasibility of their doing so. If some civil wars effectively contain a greed component (Collier and Hoeffler, 2004), then, as Collier et al. propose, 'a key prediction is that the higher the payoff from victory, the longer would be the warranted rebellion' (2004: 254). Rebellion is seen as an investment in this case, and economic sanctions, by restricting the expected benefits of resource control and export, may alter parties' incentives to prolong a conflict. Likewise, in the conceptualization of war and rebellion as a business, groups have an incentive to continue fighting when the general state of lawlessness makes contraband and other illegal activities possible and highly profitable (Collier, 2000). Perhaps the clearest example of measures seeking to limit such incentives is diamond sanctions which seek to control illicit trade and thus limit the funding of rebel groups.

Yet, independently of the underlying motivations for continuing a war, its durability is going to be crucially influenced in the short term by both financial and military viability ${ }^{7}$ (Buhaug et al., 2002; Fearon, 2004). Economic sanctions are especially designed to try to limit such viability by curtailing the arms procurements, illicit flows and the collection of public revenues from trade and foreign aid. For instance, a trade embargo may decrease the exports of goods thereby affecting the resources available to the government. As for the rebel side, sanctions are usually aimed at limiting the funding some of these groups obtain through contraband. For example, it

\footnotetext{
${ }^{7}$ This process is also known as the feasibility mechanism (Humphreys, 2005).
} 
is argued that the Lancaster House agreement (1979) that put an end to the conflict in Rhodesia was in part made possible by the extensive UN sanctions imposed in 1966, which forbade trade (the insuring of commodities or goods, exports and imports from Rhodesia) as well as financial exchange with the target country, and so weakened Ian Smith's government and forces. The diamond embargo recently imposed on Ivory Coast (2005) is intended to reduce the revenues raised from export and production by the rebels of the New Forces (Wallensteen et al., 2006). Diamond sanctions have been imposed against UNITA in Angola (along with petroleum sanctions), Sierra Leone and Liberia. It is argued that the 2001 diamond sanctions on Liberia were effective in reducing government revenues and, consequently shortening the conflict (Wallensteen et al., 2006). If properly enforced, all of them are principally designed to cut to some extent the flow of monetary and military resources into the hands of the contending parties (especially the rebels).

So let us frame, relying on both the arguments against sanctions usefulness and, alternatively, on the two basic mechanisms just mentioned above in favour of a sanctions' role in shortening conflicts, the following two basic hypotheses:

Hypothesis 1.a: Sanctions, as a sort of external intervention, are negatively related to the probability of war end.

Hypothesis 1.b: The duration of civil war is decreased by the imposition of sanctions.

The debate over sanctions does not only revolve around whether they might be counterproductive or effective. The apparent reliance for sanctions' success on the costs imposed on targets compelled governments and scholars to discuss and assess the type of cost that should be inflicted, and what actor or group should be the target in order to maximize effectiveness. As mentioned above, the distinction in this case is between comprehensive sanctions or the so-called smart - or targeted - sanctions. The former are intended to maximize general costs on target. Instead, advocates of smart sanctions stress that targeted measures maximize the cost on the specific group whose obedience is sought while avoiding the general population's suffering. Kaempfer and Lowenberg assert that 'the sanctions which are most likely to precipitate the desired political change in the target country are those which concentrate income losses on groups benefiting from the target government's policy' (1988: 792). On the contrary, Gershenson (2002) formally shows that it is the strength of sanctions that affects the allocation of resources to conflict and the utility of the contending parties. In fact, the existing evidence 
suggests that comprehensive sanctions are more effective (Cortright and Lopez, 2002), and many studies have identified that the bigger the costs imposed on the target, the higher the likelihood of coercion episodes success (Hufbauer et al., 1990, 2007; DashtiGibson et al., 1997; Drury, 1998; Nooruddin, 2002) ${ }^{8}$. Furthermore, some partial evidence on some specific types of smart sanctions tends to support the more pessimistic view about their lack of effectiveness. For instance, one of the most widely used coercive measure in cases of civil conflict, international arms embargoes, is argued to be largely irrelevant (Tierney, 2005). The reasons exposed for that failure comprise the exemption of the Security Council members from the restrictions, the incentives to free-riding suppliers, weak enforcement, late application, or the reinforcing of power asymmetries between parties (Tostensen and Bull, 2002; Tierney, 2005). In clear contrast, Strandow (2006) contends that arms embargoes, given that they directly target actors' military power, should be the most effective type of targeted measure - if properly implemented - in increasing the likelihood of conflict resolution by favouring the convergence of beliefs over each party capacity. In this paper I attempt to evaluate and to compare the relationship between different types of measures, such as total economic embargoes, arms embargoes, trade restrictions, and aid cuts (most generally contained in sanction episode) and the duration of civil wars. The above statements are summarized in the following hypothesis

Hypothesis 2: Sanctions that maximize costs on the target (total embargoes) should decrease the duration of civil conflicts.

Another way of studying and classifying sanctions consists of focusing on those that apply such measures, the senders. At this respect, international sanctions are either multilateral or unilateral or, more specifically, are imposed either by international institutions or by other bodies (one state or a small coalition of them). As outlined above, some evidence tends to support the view that unilateral sanctions tend to be more effective tan multilateral ones (Drezner, 1999; Hufbauer et al., 1990; Kaempfer and Lowenberg, 1999), precisely due to the problems outlined above present in targeted measures such as arms embargoes, namely, free-riding and enforcement difficulties. Nevertheless, more recent studies relying on a new dataset, find that in fact multilateral sanctions have been more effective (Bapat and Morgan, 2007). Drezner (2000) points to the possibility that the key variable is not whether sanctions are multilateral or not but

\footnotetext{
${ }^{8}$ Lektzian and Souva (2007) argue the costly sanctions are only effective when imposed against democratic states due to the bigger size of their winning coalitions.
} 
whether those multilateral sanctions are imposed by an international organization. International organization involvement prevents backsliding and ensures the maintenance of the commitment to cooperate with the sanctioning collation. This, in turn, increases the senders' capability to impose a greater cost on the target country, which seems to be main underlying cause of sanction episodes' success or failure. Regardless of this capacity to impose bigger costs and turning to the specific context of civil conflict, the involvement of an international organization in a conflict has other implications, as it is argued to provide parties with a signal that an outside actor is willing to step in to guarantee the terms of a potential settlement (Walter, 1997). So, given the inconclusiveness of the ongoing debate, one of the questions I want to shed light on in this paper relates to the specific case of civil conflicts: Are sanctions imposed by international institutions more effective than others in shortening intrastate conflicts? In light of these last claims reviewed above we hypothesize

Hypothesis 3: Sanctions that are imposed by some multilateral international organization should be more effective in decreasing internal conflict duration than those which are not.

Furthermore, I will investigate the impact of both types of sanction senders on the type of civil war termination (military victory vs. negotiated settlement). This will allow us to partially assess the role of international institutions in promoting peace, at least, through the use of coercive measures. The same will be done with the different types of sanctions.

\section{Data and Methods}

In order to answer to all the questions posed above, I use a large dataset on civil wars covering the period from 1959 to 1999. Data on intrastate conflict have been complied from Fearon and Laitin (2003), Humphreys (2005) and Fearon (2004, 2005), and include 87 civil war episodes occurring in 63 countries $^{9}$. Since the data have a timeseries cross-section format, we can better control for the variability in the years in which a country is under economic sanctions and a civil conflict is ongoing. With regard to the dependent variable, in the first part of the analysis I use a binary variable which indicates whether the war ends in a given year. Hence, the variable, 'civil war end', can

\footnotetext{
${ }^{9}$ The list constructed by Fearon and Laitin (2003) covers those conflicts that meet the following primary criteria: i) they involved fighting between agents of the state and organized non-state groups; ii) the conflict killed at least 1,000 over its course, with a yearly average of at least 100; iii) at least 100 were killed on both sides. For the secondary criteria, see Fearon and Laitin (2003).
} 
take two values, 1 if the war ends and 0 if the war is ongoing in a given year. For the second part of the analysis, I take the variable used by Humphreys $(2005)^{10}$, which codes the mode of conflict termination, and may take three values: 0 if the conflict is ongoing in that year, 1 if the conflict is resolved through military means, and 2 if the war ends through a negotiated settlement.

Data on sanction episodes are taken from Marinov's (2005) dataset, which recast Hufbauer et al.'s (1990) dataset in country-year format and updated it. These data have been contrasted, widened and improved using the Threat and Imposition of Sanctions (TIES henceforth) dataset, which collected data on instances of both the threat and the implementation of sanctions during the period 1971-2000 (Morgan et al., 2006) ${ }^{11}$. As Bapat and Morgan (2007) remark, the dataset of Hufbauer et al. (1990) covers 116 cases of sanctions (between 1914 and 1990), whereas the TIES dataset includes 529 instances of sanctions imposition. Moreover, the TIES dataset classifies episodes according to the type of sanctions along two basic dimensions: The type of measure applied, and whether sanctions were imposed by an international institution. Thus, I have constructed two more variables: The first, 'Institutional sanction', takes the value 0 if no sanction is imposed, 1 if a country is under sanctions not imposed by an international institution, and 2 if a country is under sanctions imposed by an international institution in a given year. The second variable distinguishes between the main types of measure adopted: Total economic embargoes, multilateral arms embargoes (UN, EU and other multilateral embargoes $)^{12}$, restrictions on imports and exports, the termination of foreign aid and other measures (such as asset freezes, travel bans, suspension of agreements and blockades). Finally, I have also constructed a variable that distinguishes between threats of sanctions and imposed sanctions. As mentioned above, the analyses on sanctions effectiveness may suffer from selection bias. The bias problem lies in the fact that threats of sanctions might be more successful that imposed ones but they are generally not observed. So, as Drezner (2003a) argues, to test the selection argument, we need to study those cases in which sanctions are threatened but not implemented. Fortunately, the new TIES data set contains also information on threat episodes that did not ended up with the imposition of sanctions. Therefore, our variable 'sanction threat' is coded 0 if

\footnotetext{
${ }^{10}$ Humphreys compiled it from Barbara Walter (2002).

${ }^{11}$ See also Bapat and Morgan (2007).

${ }^{12}$ As TIES dataset does not include a category for arms embargoes, and given the policy relevance of international arms embargoes, we have constructed a dummy for arms embargoes imposed by international organizations. Data have been taken from Fruchart et al. (2007) and the SIPRI website: www.sipri.org/contents/armstrad/embargoes.html.
} 
no threat or sanction is applied, 1 if a country is threatened but eventually sanctions are not imposed, and 2 if sanctions are imposed.

We consider a number of control variables which refer to commonly identified factors included in recent studies on civil war duration. These include, on the viability side, the percentage of the terrain that is mountainous and forested, which are frequently argued to increase the capacity of the rebels; I also include the number of bordering states and the size of the army (per 1,000 inhabitants), obtained by dividing the size of the army by the total population ${ }^{13}$. I also control for the degree of ethnic diversity in the country $^{14}$. To capture the possibility of financing through contraband, I include the dummy variable constructed by Fearon, which is coded 1 if there is 'evidence of major reliance by the rebels on income from production or trafficking in contraband' (2004: 284), 0 otherwise.

On the socioeconomic side, I include the logarithm of the country's population and per capita GDP. As for the presence of natural resources and primary commodities, I have compiled several variables from different sources. First, I use two dummy variables. The first, 'mineral resources', takes the value 1 if the average ratio of ore and mineral exports in any year for which a country has data exceeded $50 \%$ of total merchandise exports, 0 otherwise ${ }^{15}$. The second variable, 'oil-producing country', is coded 1 for those country-years in which fuel exports exceeded one-third of total export revenues, 0 otherwise ${ }^{16}$. I have also used the variables on oil production and reserves and diamond production (expressed both in total production and in per capita terms) developed by Humphreys (2005).

As stressed above, Pape $(1997,1998)$ argues that sanctions basically do not work since any policy effect observed so far is actually due to the use of force that some times accompanies them. To control for this possibility, I include the dummy variable 'military intervention', which is coded 1 for each country-year in which some sort of military intervention, as categorized by Regan (2002), takes place.

The literature also suggests some other relevant controls, such as the logarithm of the average number of deaths per year as compiled by Fearon (2004). And also compiled from Fearon (2004), some dummies capturing the type of ongoing civil war

\footnotetext{
${ }^{13}$ These variables have been all compiled from DeRouen and Sobek (2004).

${ }^{14}$ The data have been compiled from Fearon (2003). Fearon's variable measures the probability that two randomly selected persons from a given country will not belong to the same ethnic group.

${ }^{15}$ Variable compiled from Gandhi and Przeworski (2006).

${ }^{16}$ This variable has been compiled from Fearon and Laitin (2003).
} 
are considered. The first is 'ethnic war', which takes value 1 if the ongoing war is of an ethnic nature ${ }^{17}$. The second dummy takes value 1 if the war is classified as a 'sons of the soil' conflict. As defined by Fearon (2004), these are wars resulting from countries in which the state is dominated by an ethnic group facing population pressure. When they migrate to less populated areas, often with the support of the state, the ethnic minorities living in those regions often take up arms against the migrants and the state.

The methodology employed consists basically in logistical regressions, both binary, to analyze the likelihood of conflict termination, and multinomial, to analyze the mode in which the war ends (i.e., military victory or negotiated settlement). As usual when duration is analyzed using discrete-time data, the potential time dependence in the data is corrected by including natural cubic splines on the right-hand side of the equation to be estimated (Beck et al., 1998). Errors have been clustered.

\section{Analyses and Results}

\subsection{Civil War Termination and Economic Sanctions}

I begin by enquiring whether sanctions have any effect on the length of intrastate conflicts in a simple manner. Figure I portrays, using the non-parametric Kaplan-Meier estimate, the survival curves of those conflicts under sanctions versus those not under. The differences between the groups are substantial and suggest a significant correlation between the two variables. As the plot reveals, the proportion of ongoing wars is clearly smaller for those cases targeted by international economic sanctions. ${ }^{18}$ This preliminary evidence suggests that international sanctions are related to the decline of the survival rate of intrastate wars.

[Figure 1 in here]

Moving on to the multivariate analyses, Table I reports the estimated coefficients of the binary logistic regressions used to estimate the impact of economic sanctions with the aim of testing our first hypotheses. In columns 1-3 I include the sanctions dummy, while in columns 4 and 5 I include the variable 'sanctions duration', which is a measure that cumulates the number of years a country has been under

\footnotetext{
${ }^{17}$ We have only coded as 1 those cases with value 3, excluding, thus, those considered mixed or ambiguous by the author.

${ }^{18}$ The variable 'sanction' only includes sanctions actually imposed, not threats.
} 
sanctions in a given year. ${ }^{19}$ The results serve to reject hypothesis 1.a and confirm hypothesis 1.b: both sanctions and their duration (in years) are significantly associated with a higher likelihood of civil war termination. These results are robust to the inclusion of the variable 'military intervention' and to the use of alternative measures of natural resource availability. Note that the effect of a military intervention is negative as previous research had already indicated, but not significant. Being under sanctions involves an increase of 0.044 in the probability of conflict termination (according to the estimates in column 1), while a one-unit change in the time a country has been targeted by sanctions increases the probability of war termination by 0.0041 points (column 4 ). ${ }^{20}$ The computed probability of civil war termination when a country has been just one year under coercive sanctions is 0.0384 , whereas the probability of termination for a country that has been targeted for five years is 0.0572 .

[Table I in here]

Column 6 includes the distinction between sanction threats and effectively imposed sanctions. The number of observations gets reduced in this case as the sample is restricted to the TIES data, so it starts in 1971. Threats that not ended with the imposition of sanctions have an important positive effect on the likelihood of conflict end but the relationship is not statistically significant, probably due to the reduced number of such instances in our sample.

I now move on to examine the effects of different types of sanctions. In the first column of Table II the estimates using the categorization of sanctions according to the kind of measure adopted against the target. This model is restricted to the TIES sample (from 1971), so the number of observations is lower. The results tend to confirm hypothesis 2 and make clear that it is basically comprehensive sanctions directed towards cutting the total flow of funds to the rival parties that have significant and negative effects on the duration of intrastate conflicts. The examination of the marginal effects of each of the types included in the regression reveals that comprehensive sanctions (total embargoes) are the most effective measure in shortening civil wars, followed by trade restrictions (of exports and imports), which include commodity

\footnotetext{
19 Therefore, in this case, sanctions are not considered just as a constant variable, but as a steadily increasing value over time, as it is assumed that the more the number of years a given country is targeted the higher are the accumulated costs. See Collier et al. (2004) for a similar methodology applied to outside interventions.

${ }^{20}$ The rest of the variables are held constant at their means.
} 
sanctions. ${ }^{21}$ Concretely, the increases in the probability of war termination when those dummies change from 0 to 1 are 0.30 and 0.075 , respectively. Multilateral arms embargoes do not appear to have any significant effect on civil war duration.

[Table II in here]

With regard to whether sanctions are imposed by an international institution, the results in column 2 reveal that, when no further distinction is introduced in the dependent variable, the impact of both kinds of sanctions is almost identical in size. The changes in the likelihood of war termination are 0.050 and 0.057 when these two dummy variables increase from 0 to 1 , respectively. Although it is true that the effect of those sanctions imposed by international institutions is bigger, the negligible differences in the size of both effects give little support to hypothesis 3 . In the next section I examine whether these sanctions are associated with different war outcomes.

As for the rest of the variables, their estimated patterns conform to some of the evidence already provided by previous research. In line with Humphreys' (2005) results, the production of diamonds and the export of minerals in fact tend to shorten civil wars. Confirming Fearon's (2004) findings, I also find that contraband hinders conflict resolution, and that 'sons of the soil' wars tend to last longer than other types of conflict. Ethnic wars are slightly shorter, but the effect is not significant. Furthermore, the size of the army is related to longer wars (as already observed by DeRouen \& Sobek, 2004), while the number of fatalities tend to shorten them as well as the GDP per capita. I find a curvilinear relationship between ethnic fractionalization and conflict duration too. The geographic characteristics of the country do not have any significant effect in these pooled regressions, only mountainous terrain in column 6 .

\subsection{Civil War Outcomes and the Effect of Sanctions}

Not all civil wars end in the same way, so outcomes may need to be treated as competing risks. According to our sample, and following the codification developed by Walter (2002), 49 of the 66 civil conflicts that finished within the period under study ended because of a military victory of one of the sides, while 17 ended through a negotiated settlement. I want to investigate whether sanctions imposed by an international institution are more conductive to negotiated settlements, whereas those

\footnotetext{
${ }^{21}$ Trade restrictions are almost significant, the $p$-value of this variable is just 0.105 .
} 
which do not involve an international organization are more prone to lead to military victories. The method employed to test this proposal is, in this case, multinomial logit.

The estimates are reported in Table III. The likelihood of each war outcome is strongly influenced by the existence of sanctions in the direction pointed out (see models 1 and 2). As it is clearly revealed, sanctions, albeit generally helping to reduce conflict length, do so with different consequences. Sanctions imposed by international institutions significantly increase the probability of reaching a negotiated settlement that brings the conflict to an end. Increased cooperation between senders augments the costs and efficacy of sanctions episodes. Moreover, the intervention of an international organization signals the parties that an outside actor may intervene to guarantee the terms of a potential settlement (Walter, 1997), so the utility of a pact increases as the likelihood of a unilateral defection are diminished by a third-actor. On the other hand, those sanctions unilaterally imposed by individual countries or a small coalition of them have an important impact on the probability of a civil war ending through military means. One possible reason (needing further study) why this is so may be that those sanctions not under the direction of an international multilateral institution may be biased and possibly inspired by the domestic interests of the primary sender.

[Table III in here]

In model 3 a further refinement to our variable on multilateral sanctions has been introduced. It can be argued that sanctions imposed by international institutions will tend to be more effective if the target country is itself a member of the multilateral institution. Greater diplomatic contact, military cooperation and commercial interdependence are likely to be found among the members of some multilateral organizations. To test this straightforward proposition I have recoded the variable used in model 1 by dividing the sanctions imposed by an international institution into two extra dummy variables: the first is coded 1 if the country is being sanctioned by an international institution but is not member of that institution, and the second is coded 1 if the country is being sanctioned by an international institution to which it belongs. The coefficients of the newly created dummies largely confirm our expectations. Note first that the strong positive impact of 'non-institutional' sanctions on military victory is not altered. In contrast, for those countries belonging to the institution imposing the sanctions, the impact of such coercive measures is great and significant. The estimated probability of a negotiated settlement is 0.0008 when no sanction is present; if the country is targeted by sanctions of an international institution it belongs to, the 
probability of a negotiated termination is 0.024 . On the other hand, a country under noninstitutional sanctions faces a probability of 0.074 of having the conflict resolved through military means, while if no sanction is imposed, the likelihood is just 0.023 .

Table IV shows the results of the effects of the types of measure sanctions involve on war outcome. These results should be carefully interpreted as they are quite sensitive to sample size, which in this case is restricted to the TIES data (from 1971). To increase the number of observations the variable 'log GDP per capita' has been ruled out since it was not significant anyway, and we use the natural resources dummies. The evidence suggests that the only measures effective in shortening conflicts are total embargoes, which increase the likelihood of both a military victory and a settlement. In contrast, international arms embargoes have a negative and significant impact on the probability of a military victory. This result gives credit to those arguing that this type of sanction has been irrelevant at best, and even counterproductive (Tierney, 2005). Multilateral arms embargoes may re-balance the power between parties thereby making victory less likely. On the other hand, multilateral arms embargoes have had a positive, albeit not significant, effect on the likelihood of a settlement. ${ }^{22}$ This latter finding supports to some extent the proposition that arms embargoes decrease uncertainty over each party's power.

\section{[Table IV in here]}

Other results of these tables merit comment: military interventions significantly reduce the likelihood of a settlement. The inclusion of this variable reduces somewhat the sample and slightly alters some of the results. Again, contraband reduces the prospects of conflict termination, especially those of a military victory as it allows the rebels to finance their activities. The number of borders has contradictory effects. On the one hand, it serves to hinder a military victory (arguably, by government forces), since it eases the maintenance of rebel bases outside the boundaries of the state; but, on the other hand, it increases the likelihood of a negotiated resolution like in DeRouen \& Sobek (2004). The size of the army also represents a significant obstacle to a negotiated resolution of conflicts as it may tend to make the government overestimate its relative strength, $p_{e}$, and the probability of winning (Mason \& Fett, 1996). Natural resources, both diamonds and oil, are again related to shorter wars, although through different

\footnotetext{
${ }^{22}$ The coefficient is almost significant at the 0.10 level; the $p$-value is 0.105 .
} 
mechanisms. Abundant forest areas increase the likelihood of a military victory and hinder negotiated settlements.

\section{Concluding Remarks}

Studies of the efficacy of economic sanctions have tended to analyze it in a rather general way and using constructed variables that often assess the success of a sanction episode on an ordinal scale. In this work I sought to explore the effect of sanctions in a very specific context, civil war duration, using a time-series crosssectional dataset and a direct measure of event occurrence, civil war termination and outcome.

I hypothesized that sanctions would have a significant negative effect on intrastate conflict duration, mainly due to three basic mechanisms: convergence of parties' beliefs over power, reduced utility of victory and financial pressure that reduce parties' viability of continued fighting. Our second proposition contended that those sanctions maximizing the costs to the target would be more effective than other types of targeted measures in bringing war to and end. Finally, I further proposed that those sanctions imposed by an international institution would be more effective in augmenting the probability of intrastate conflict termination.

Our empirical evidence using new data on sanctions shows that, effectively, sanctions have had a significant and negative impact on intrastate conflict duration. Moreover, this effect augments the more the years a given country is targeted. These results are robust to the inclusion of a variable controlling for external military interventions. Moreover, the empirical evidence seems to suggest that the most successful measures so far have been total economic embargoes. Such measures are shown to increase the likelihood of both a military victory and a negotiated settlement, while international arms embargos are only found to significantly decrease the likelihood of a military victory by one the parties.

Regarding the debate about the efficacy of sanctions imposed by international institutions or not, this article has shed light on the distinctive effect of both types of sanction. Although the coefficients for sanctions backed by international institutions and those which are not are extremely similar in size in the general models of war duration, I find that sanctions imposed by international institutions significantly increase the likelihood of conflict resolution, especially if the targeted country is a member of the 
organization. In contrast, sanctions applied by other bodies are much more conducive to military victories.

In sum, the article has several policy implications. First, it suggests that, overall, sanctions have been relatively useful in helping shortening civil wars, as the statistical association suggests. Yet, this role needs improving. Concretely, our results suggest that any coercive measure should be preferably conducted by international organizations, especially, if it is conflict resolution what we are interested to promote. Concerning the measures imposed, the evidence suggests that maximizing costs via embargoes is more effective than other sanction types. Multilateral arms embargoes can also result in increased chances of negotiated settlement, although implementation problems so far have limited their effectiveness as remarked by many scholars. 
Figure 1. Proportion of civil wars ongoing by year

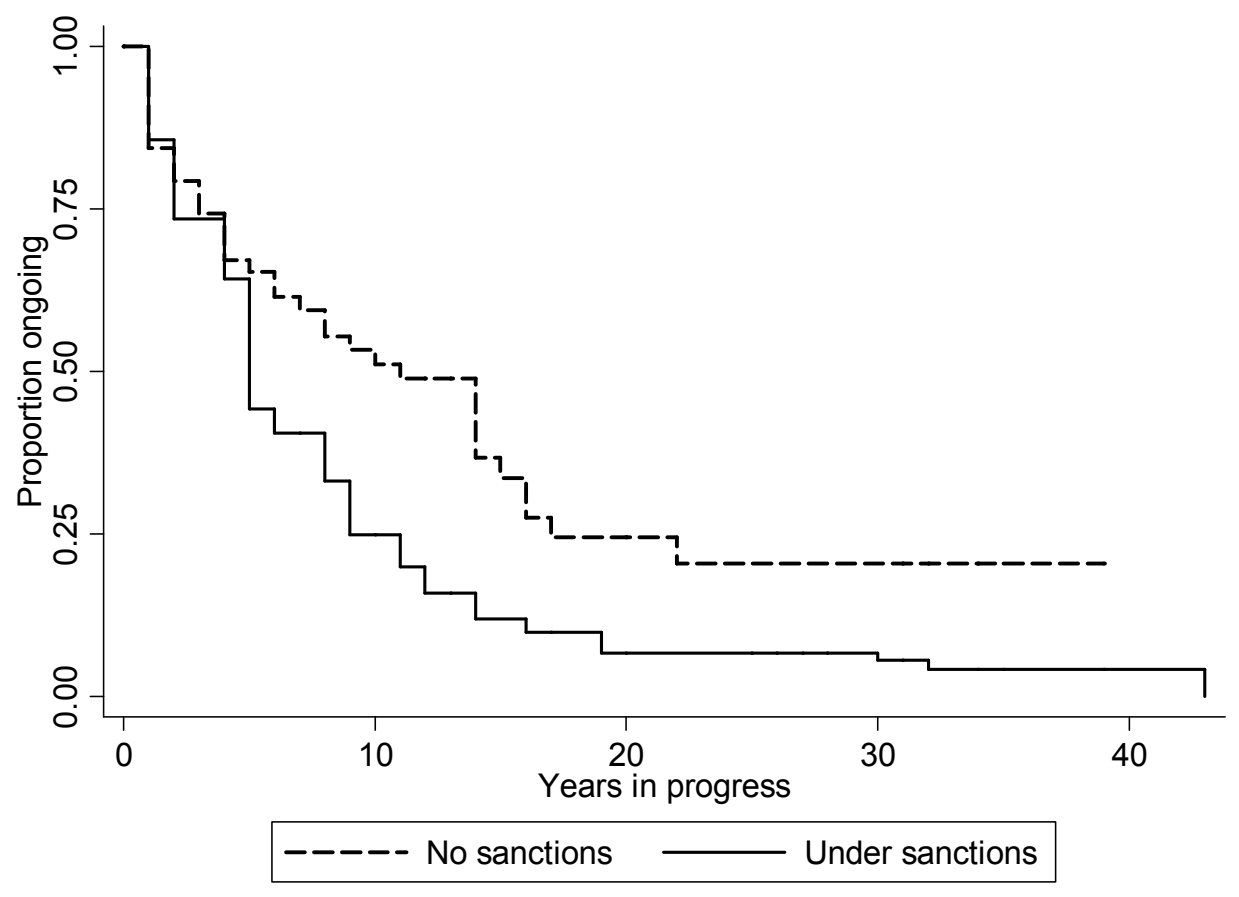


Table I. Sanctions and civil war duration (logistic regression)

\begin{tabular}{|c|c|c|c|c|c|c|}
\hline \multirow[b]{2}{*}{ Independent variables } & \multicolumn{6}{|c|}{ Event: Civil war end $=1$} \\
\hline & $(1)$ & $(2)$ & (3) & (4) & $(5)$ & $(6)$ \\
\hline \multirow[t]{2}{*}{ Intercept } & 2.32 & 2.59 & 2.23 & $3.87 *$ & 3.53 & 2.34 \\
\hline & $(1.86)$ & $(1.65)$ & $(2.15)$ & $(2.33)$ & $(2.65)$ & $(2.18)$ \\
\hline \multirow[t]{2}{*}{ Mountains } & -0.007 & -0.003 & -0.009 & -0.008 & -0.009 & $-0.017 *$ \\
\hline & $(0.006)$ & $(0.007)$ & $(0.007)$ & $(0.007)$ & $(0.008)$ & $(0.009)$ \\
\hline \multirow[t]{2}{*}{ Forests } & -0.001 & 0.006 & 0.003 & -0.003 & 0.002 & -0.004 \\
\hline & $(0.009)$ & $(0.009)$ & $(0.011)$ & $(0.010)$ & $(0.011)$ & $(0.012)$ \\
\hline \multirow[t]{2}{*}{ Log population } & -0.119 & -0.070 & -0.202 & -0.120 & -0.225 & -0.383 \\
\hline & $(0.231)$ & $(0.236)$ & $(0.263)$ & $(0.244)$ & $(0.285)$ & $(0.289)$ \\
\hline \multirow[t]{2}{*}{ Log GDP per capita } & $-0.546^{* *}$ & $-0.635 * *$ & -0.398 & $-0.794 * *$ & $-0.608 *$ & -0.304 \\
\hline & $(0.250)$ & $(0.287)$ & $(0.292)$ & $(0.315)$ & $(0.328)$ & $(0.328)$ \\
\hline \multirow[t]{2}{*}{ Mineral exporting } & $2.13 * * *$ & & $2.73 * *$ & $2.97 * * *$ & $3.65^{* * *}$ & $2.83 * *$ \\
\hline & $(0.789)$ & & $(1.19)$ & $(1.01)$ & $(1.41)$ & $(1.30)$ \\
\hline \multirow[t]{2}{*}{ Oil exporting } & 0.285 & & 0.245 & 0.603 & 0.557 & -0.161 \\
\hline & $(0.419)$ & & $(0.436)$ & $(0.484)$ & $(0.499)$ & $(0.521)$ \\
\hline \multirow[t]{2}{*}{ Oil production } & & 6.32 & & & & \\
\hline & & $(6.33)$ & & & & \\
\hline \multirow[t]{2}{*}{ Diamond production } & & $1.67 * *$ & & & & \\
\hline & & $(0.845)$ & & & & \\
\hline \multirow[t]{2}{*}{ Ethnic fractionalization } & $7.09 * * *$ & $5.45^{*}$ & $6.44 *$ & $10.48 * * *$ & $10.24 * *$ & $9.19 * *$ \\
\hline & $(2.52)$ & $(2.94)$ & $(3.40)$ & $(0.343)$ & $(4.81)$ & $(4.22)$ \\
\hline \multirow[t]{2}{*}{$(\text { Ethnic fractionalization })^{2}$} & $-8.02 * * *$ & $-6.28 * *$ & $7.42 * *$ & $-11.99 * * *$ & $-11.77 * *$ & $-10.48 * *$ \\
\hline & $(2.65)$ & $(3.14)$ & $(3.36)$ & $(3.68)$ & $(4.83)$ & $(4.27)$ \\
\hline \multirow[t]{2}{*}{ Contraband } & $-1.65 * * *$ & $-1.44 * *$ & $-1.68 * * *$ & $-1.77 * * *$ & $-1.79 * *$ & $-1.45^{* *}$ \\
\hline & $(0.527)$ & $(0.583)$ & $(0.614)$ & $(0.624)$ & $(0.717)$ & $(0.604)$ \\
\hline \multirow[t]{2}{*}{ Number of borders } & -0.066 & -0.094 & -0.033 & -0.112 & -0.069 & 0.099 \\
\hline & $(0.078)$ & $(0.085)$ & $(0.082)$ & $(0.090)$ & $(0.095)$ & $(0.084)$ \\
\hline \multirow[t]{2}{*}{ Army size (log) } & $-0.353 *$ & $-0.338 *$ & $-0.393 *$ & $-0.334 *$ & $-0.405 *$ & -0.336 \\
\hline & $(0.184)$ & $(0.195)$ & $(0.226)$ & $(0.202)$ & $(0.238)$ & $(0.290)$ \\
\hline \multirow[t]{2}{*}{ Deaths/year } & $4.13 \mathrm{e}-06^{*}$ & $3.93 \mathrm{e}-06^{*}$ & $6.21 \mathrm{e}-06^{* *}$ & $4.10 \mathrm{e}-06^{*}$ & $6.24 \mathrm{e}-06^{* *}$ & $0.00001 * * *$ \\
\hline & $(2.18 \mathrm{e}-06)$ & $(2.17 \mathrm{e}-06)$ & $(2.54 \mathrm{e}-06)$ & $(2.26 \mathrm{e}-06)$ & $(2.67 \mathrm{e}-06)$ & $(4.14 \mathrm{e}-06)$ \\
\hline \multirow[t]{2}{*}{ Ethnic war } & 0.563 & 0.540 & 0.512 & 0.598 & 0.636 & 0.619 \\
\hline & $(0.470)$ & $(0.463)$ & $(0.580)$ & $(0.503)$ & $(0.595)$ & $(0.614)$ \\
\hline \multirow[t]{2}{*}{ Sons of soil war } & $-2.11 * * *$ & $-2.08 * * *$ & $-2.06 * * *$ & $-2.32 * * *$ & $-2.24 * * *$ & $-1.85 * * *$ \\
\hline & $(0.730)$ & $(0.740)$ & $(0.750)$ & $(0.662)$ & $(0.679)$ & $(0.533)$ \\
\hline \multirow[t]{2}{*}{ Military intervention } & & & -0.606 & & -0.566 & -0.563 \\
\hline & & & $(0.541)$ & & $(0.565)$ & $(0.529)$ \\
\hline \multirow[t]{2}{*}{ Economic sanctions } & $0.847 * * *$ & $0.885 * * *$ & $0.883^{* * *}$ & & & \\
\hline & $(0.293)$ & $(0.291)$ & $(0.316)$ & & & \\
\hline Sanction duration & & & & $0.104 * * *$ & $0.096 * * *$ & \\
\hline & & & & $(0.028)$ & $(0.029)$ & \\
\hline Threat & & & & & & 1.34 \\
\hline & & & & & & $(1.06)$ \\
\hline Imposed sanction & & & & & & $0.921 * * *$ \\
\hline & & & & & & $(0.341)$ \\
\hline Duration splines & yes & yes & yes & yes & yes & yes \\
\hline Observations & 663 & 619 & 638 & 663 & 638 & 565 \\
\hline Log-pseudolikelihood & -151.90 & -148.01 & -138.34 & -150.34 & -137.46 & -123.27 \\
\hline Pseudo R-squared & 0.1309 & 0.1232 & 0.1359 & 0.1398 & 0.1414 & 0.1615 \\
\hline
\end{tabular}


Table II. Sanction types and the duration of civil war (logit)

\begin{tabular}{|c|c|c|}
\hline \multirow[b]{2}{*}{ Independent variables } & \multicolumn{2}{|c|}{ Event: Civil war end $=1$} \\
\hline & $(1)$ & $(2)$ \\
\hline \multirow{2}{*}{ Intercept } & 3.04 & 2.73 \\
\hline & $(2.33)$ & $(2.07)$ \\
\hline \multirow[t]{2}{*}{ Mountains } & -0.013 & -0.010 \\
\hline & $(0.011)$ & $(0.007)$ \\
\hline \multirow[t]{2}{*}{ Forests } & -0.011 & 0.001 \\
\hline & $(0.015)$ & $(0.012)$ \\
\hline \multirow[t]{2}{*}{ Log population } & -0.212 & -0.197 \\
\hline & $(0.303)$ & $(0.268)$ \\
\hline \multirow[t]{2}{*}{ Log GDP per capita } & -0.487 & -0.438 \\
\hline & $(0.317)$ & $(0.315)$ \\
\hline \multirow[t]{2}{*}{ Mineral exporting } & $3.65 * * *$ & $2.64 * *$ \\
\hline & $(1.33)$ & $(1.20)$ \\
\hline \multirow[t]{2}{*}{ Oil exporting } & 0.593 & 0.437 \\
\hline & $(0.580)$ & $(0.432)$ \\
\hline \multirow[t]{2}{*}{ Ethnic fractionalization } & $7.84^{*}$ & $6.38^{*}$ \\
\hline & $(4.36)$ & $(3.58)$ \\
\hline \multirow[t]{2}{*}{$(\text { Ethnic fractionalization })^{2}$} & $-9.54 * *$ & $-7.45 * *$ \\
\hline & $(4.67)$ & $(3.56)$ \\
\hline \multirow[t]{2}{*}{ Contraband } & $-1.84 * * *$ & $-1.76 * * *$ \\
\hline & $(0.631)$ & $(0.628)$ \\
\hline \multirow[t]{2}{*}{ Number of borders } & 0.144 & -0.022 \\
\hline & $(0.095)$ & $(0.088)$ \\
\hline \multirow[t]{2}{*}{ Army size (log) } & $-0.537 *$ & $-0.403^{*}$ \\
\hline & $(0.307)$ & $(0.232)$ \\
\hline \multirow[t]{2}{*}{ Deaths/year } & $9.04 \mathrm{e}-06^{*}$ & $4.26 \mathrm{e}-06$ \\
\hline & $(4.87 \mathrm{e}-06)$ & $(3.11 \mathrm{e}-06)$ \\
\hline \multirow[t]{2}{*}{ Ethnic war } & 0.418 & 0.372 \\
\hline & $(0.579)$ & $(0.580)$ \\
\hline \multirow[t]{2}{*}{ Sons of soil war } & $-2.28 * * *$ & $-2.12 * * *$ \\
\hline & $(0.675)$ & $(0.828)$ \\
\hline \multirow[t]{2}{*}{ Military intervention } & -0.645 & -0.608 \\
\hline & $(0.540)$ & $(0.532)$ \\
\hline \multirow[t]{2}{*}{ Non-institutional sanction } & & $0.940^{* *}$ \\
\hline & & $(0.390)$ \\
\hline \multirow{2}{*}{$\begin{array}{l}\text { International institution } \\
\text { sanction }\end{array}$} & & $1.01 *$ \\
\hline & & $(0.607)$ \\
\hline \multirow[t]{2}{*}{ Total embargo } & $2.70 * * *$ & \\
\hline & $(0.730)$ & \\
\hline \multirow[t]{2}{*}{ Aid termination } & 0.546 & \\
\hline & $(0.479)$ & \\
\hline Trade restrictions & 1.25 & \\
\hline & $(0.773)$ & \\
\hline Multilateral arms embargo & -0.627 & \\
\hline & $(1.07)$ & \\
\hline Other sanctions & 0.584 & \\
\hline & $(0.922)$ & \\
\hline Duration splines & yes & yes \\
\hline Observations & 565 & 631 \\
\hline Log-pseudolikelihood & -119.23 & -136.25 \\
\hline Pseudo R-squared & 0.1596 & 0.1322 \\
\hline
\end{tabular}


Table III. Civil war outcome and international sanctions (multinomial logit)

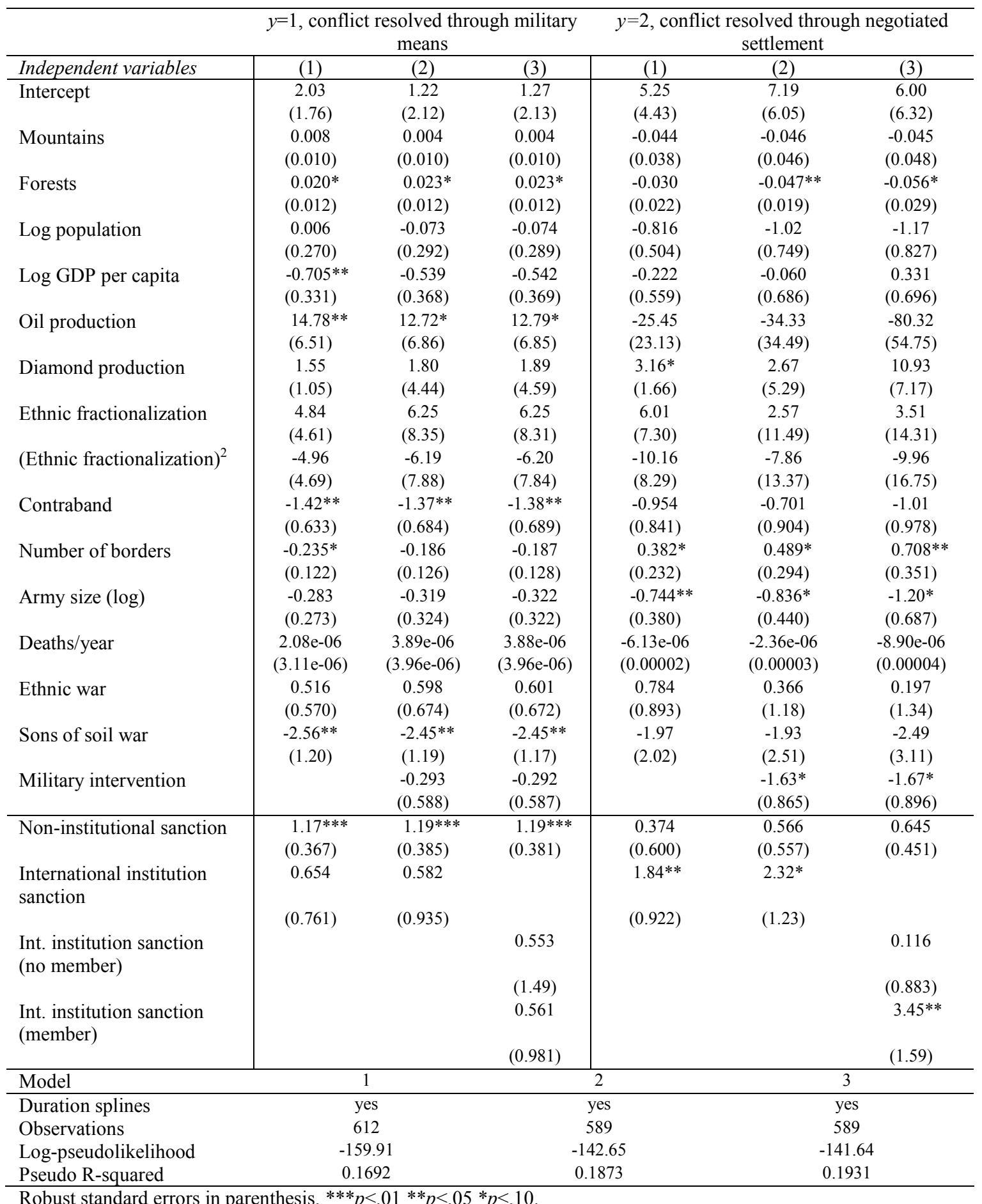


Table IV. Types of sanction and civil war outcome (multinomial logit)

\begin{tabular}{|c|c|c|}
\hline \multirow[b]{2}{*}{ Independent variables } & \multicolumn{2}{|c|}{ Event: Civil war outcome $=j$} \\
\hline & $\begin{array}{c}\text { Military } \\
\text { victory }\end{array}$ & $\begin{array}{l}\text { Negotiated } \\
\text { settlement }\end{array}$ \\
\hline Intercept & $\begin{array}{c}-0.167 \\
(0.278)\end{array}$ & $\begin{array}{c}9.09 \\
(6.15)\end{array}$ \\
\hline Mountains & $\begin{array}{l}-0.012 \\
(0.012)\end{array}$ & $\begin{array}{c}-0.041 \\
(0.043)\end{array}$ \\
\hline Forests & $\begin{array}{c}0.003 \\
(0.015)\end{array}$ & $\begin{array}{l}-0.081 * \\
(0.043)\end{array}$ \\
\hline Log population & $\begin{array}{l}-0.481 * \\
(0.261)\end{array}$ & $\begin{array}{l}-1.12 * * \\
(0.568)\end{array}$ \\
\hline Mineral exporting & $\begin{array}{l}4.71 * * * \\
(1.81)\end{array}$ & $\begin{array}{l}6.45^{* *} \\
(2.60)\end{array}$ \\
\hline Oil exporting & $\begin{array}{c}0.257 \\
(0.566)\end{array}$ & $\begin{array}{r}0.441 \\
(1.57)\end{array}$ \\
\hline Ethnic fractionalization & $\begin{array}{l}14.68 \\
(9.53)\end{array}$ & $\begin{array}{c}0.739 \\
(14.06)\end{array}$ \\
\hline$(\text { Ethnic fractionalization })^{2}$ & $\begin{array}{c}-15.84 * \\
(9.27)\end{array}$ & $\begin{array}{l}-5.58 \\
(15.22)\end{array}$ \\
\hline Contraband & $\begin{array}{l}-1.53^{* *} \\
(0.748)\end{array}$ & $\begin{array}{l}-3.08 \\
(2.14)\end{array}$ \\
\hline Number of borders & $\begin{array}{c}0.141 \\
(0.114)\end{array}$ & $\begin{array}{l}0.665^{* *} \\
(0.302)\end{array}$ \\
\hline Army size $(\log )$ & $\begin{array}{l}-0.663^{*} \\
(0.372)\end{array}$ & $\begin{array}{l}-1.56^{* * *} \\
(0.498)\end{array}$ \\
\hline Deaths/year & $\begin{array}{c}0.00001^{* *} \\
(5.64 \mathrm{e}-06)\end{array}$ & $\begin{array}{c}1.15 \mathrm{e}-06 \\
(0.00004)\end{array}$ \\
\hline Ethnic war & $\begin{array}{c}1.16 \\
(0.761)\end{array}$ & $\begin{array}{l}-0.373 \\
(1.25)\end{array}$ \\
\hline Sons of soil war & $\begin{array}{l}-2.36 * * * \\
(0.666)\end{array}$ & $\begin{array}{l}-2.56 \\
(2.34)\end{array}$ \\
\hline Military intervention & $\begin{array}{l}-0.656 \\
(0.629)\end{array}$ & $\begin{array}{l}-1.34 * * * \\
(0.490)\end{array}$ \\
\hline Total embargo & $\begin{array}{l}2.04 * * * \\
(0.634)\end{array}$ & $\begin{array}{l}6.03^{* * * *} \\
(1.98)\end{array}$ \\
\hline Aid termination & $\begin{array}{c}0.781 \\
(0.479)\end{array}$ & $\begin{array}{r}0.692 \\
(1.42)\end{array}$ \\
\hline Trade restrictions & $\begin{array}{c}0.508 \\
(0.671)\end{array}$ & $\begin{array}{c}1.60 \\
(2.08)\end{array}$ \\
\hline Multilateral arms embargo & $\begin{array}{l}-1.48 * * \\
(0.673)\end{array}$ & $\begin{array}{l}1.71 \\
(1.05)\end{array}$ \\
\hline Other sanctions & $\begin{array}{l}0.538 \\
(1.10) \\
\end{array}$ & $\begin{array}{c}1.02 \\
(1.45) \\
\end{array}$ \\
\hline Duration splines & & \\
\hline Observations & & \\
\hline Log-pseudolikelihood & & \\
\hline Pseudo R-squared & & \\
\hline
\end{tabular}




\section{REFERENCES}

Ang, Adrian U-Jin and Dursun Peksen. 2007. 'When do economic sanctions work? Asymmetric perceptions, issue salience, and outcomes.' Political Research Quarterly, 60 (1): $135-145$.

Askari, Hossein G., John Forrer, Hildy Teegen, and Jiawen Yang. 2003. Economic Sanctions: Explaining their philosophy and efficacy. Westport, CT: Praeger.

Balch-Lindsay, Dylan and Andrew J. Enterline. 2000. 'Killing time: the world politics of civil war duration, 1820-1992.' International Studies Quarterly, 44 (4): 615-642.

Balch-Lindsay, Dylan, Andrew J. Enterline, and Kyle A. Joyce. 2008. 'Third-party intervention and the civil war process.' Journal of Peace Research, 45 (3): 345-363.

Bapat, Navin A. and T. Clifton Morgan. 2007. 'Multilateral versus unilateral sanctions reconsidered: a test using new data.' Manuscript, University of North Carolina.

Beck, Nathaniel, Jonathan Katz and Richard Tucker. 1998. 'Taking time seriously: time-series-cross-section analysis with binary dependent variable.' American Journal of Political Science, 42 (4): 1260-1288.

Buhaug, Halvard, Scott Gates and Päivi Lujala. 2002. 'Lootable natural resources and the duration of armed civil conflict, 1946-2001.' Paper presented at the Annual Meeting of the Peace Science Society, Tucson, AZ, 1-3 November.

Buhaug, Halvard, Scott Gates \& Päivi Lujala. 2005. 'Geography, Strategic Ambition, and the Duration of Civil War.' Paper prepared for presentation at the Annual Meeting of the American Political Science Association, Washington DC, 1-4 September.

Collier, Paul. 2000. 'Rebellion as a quasi-criminal activity.' Journal of Conflict Resolution, 44 (6): 839-853.

Collier, Paul and Anke Hoeffler. 2004. 'Greed and grievance in civil war.' Oxford Economic Papers, 56: 563-595.

Collier, Paul, Anke Hoeffler and Mans Söderbom. 2004. 'On the duration of civil war.' Journal of Peace Research, 41 (3): 253-273.

Cortright, David and George A. Lopez. 2002. Smart Sanctions: Targeting Economic Statecraft. New York: Rowman \& Littlefield.

Cunningham, David E. 2006. 'Veto players and civil war duration.' American Journal of Political Science, 50 (4): 875-892.

Cunningham, David, Kristian S. Gleditsch and Idean Salehyan. 2005. 'Dyadic interactions and civil war duration.' Paper prepared for the $46^{\text {th }}$ Annual Convention of the International Studies Association, Honolulu, HI, 1-5 March. 
Dashti-Gibson, Jaleh, Patricia Davis, and Benjamin Radcliff. 1997. 'On the determinants of the success of economic sanctions: an empirical analysis.' American Journal of Political Science, 41 (2): 608-618.

Davis, Lance and Stanley Engerman. 2003. 'History lessons: Sanctions: neither war nor peace.' Journal of Economic Perspectives, 17 (2): 187-197.

DeRouen Jr., Karl R. and David Sobek. 2004. 'The dynamics of civil war duration and outcome.' Journal of Peace Research, 41 (3): 303-320.

Doyle, Michael W. and Nicholas Sambanis. 2000. 'International peacebuilding: a theoretical and quantitative analysis.' American Political Science Review, 94 (4): 779 801 .

Drezner, Daniel. 1998. 'Conflict expectations and the paradox of economic coercion.' International Studies Quarterly, 42 (4): 709-731.

Drezner, Daniel. 1999. The Sanctions Paradox: Economic Statecraft and International Relations. Cambridge: Cambridge University Press.

Drezner, Daniel. 2000. 'Bargaining, enforcement, and multilateral sanctions: when is cooperation counterproductive.' International Organization, 54 (1): 73-102.

Drezner, Daniel. 2003a. 'The hidden hand of economic coercion.' International Organization, 57: 643-659.

Drury, A. Cooper. 1998. 'Revisiting economic sanctions reconsidered.' Journal of Peace Research, 35 (4): 497-509.

Elbadawi, Ibrahim A. and Nicholas Sambanis. 2000. 'External interventions and the duration of civil war.' World Bank, Policy Research Working Paper 2433.

Elliot, Kimberly A. 1998. 'The sanctions glass: half full or completely empty?' International Security, 23 (1): 50-65.

Fearon, James D. 2003. 'Ethnic and cultural diversity by country.' Journal of Economic Growth, 8 (2): 195-222.

Fearon, James D. 2004. 'Why do some civil wars last so much longer than others?' Journal of Peace Research, 41 (3): 275-301.

Fearon, James D. 2005. 'Primary commodity exports and civil war.' Journal of Conflict Resolution, 49 (4): 483-507.

Fearon, James D. and David D. Laitin. 2003. 'Ethnicity, insurgency, and civil war.' American Political Science Review, 97 (1): 75-90.

Filson, Darren and Suzanne Werner. 2002. 'A bargaining model of war and peace: anticipating the onset, duration, and outcome of war.' American Journal of Political Science, 46 (4): 819-837. 
Fruchart, Damien et al. 2007. United Nations Arms Embargoes. Their Impact on Arms Flows and Target Behaviour. Sipri and Uppsala Universitet.

Gandhi, Jennifer and Adam Przeworski. 2006. 'Cooptation, Cooperation, and Rebellion under Dictatorships.' Economics \& Politics, 18 (1): 1-26.

Gershenson, Dmitriy. 2002. "Sanctions and Civil Conflict." Economica, 69 (274): 185206.

Hirshleifer, Jack. 2001. The Dark Side of the Force: Economic Foundations of Conflict Theory. Cambridge: Cambridge University Press.

Hufbauer, Gary C., Jeffrey J. Schott and Kimberley A. Elliott. 1990. Economic Sanctions Reconsidered: History and Current Policy. Washington, DC: Peterson Institute for International Economics.

Hufbauer, Gary C., Jeffrey J. Schott, Kimberley A. Elliott and Barbara Oegg. 2007. Economic Sanctions Reconsidered. Washington, DC: Peterson Institute for International Economics.

Humphreys, Macartan. 2005. 'Natural resources, conflict and conflict resolution.' Journal of Conflict Resolution, 49 (4): 508-537.

Kaempfer, William H. and Anton D. Lowenberg. 1988. 'The Theory of International Economic Sanctions: A Public Choice Approach.' The American Economic Review, 78 (4): 786-793.

Kaempfer, William H. and Anton D. Lowenberg. 1999. 'Unilateral versus multilateral international sanctions: a public choice perspective.' International Studies Quarterly, 43 (1): $37-58$.

Kydd, Andrew. 2003. 'Which side are you on? Bias, credibility, and mediation.' American Journal of Political Science, 47 (4): 597-611.

Lacy, Dean and Emerson M. S. Niou. 2004. 'A theory of economic sanctions and issue linkage: the roles of preferences, information, and threats.' Journal of Politics, 66 (1): $25-42$.

Lektzian, David and Mark Souva. 2007. 'An institutional theory of sanctions onset and success.' Journal of Conflict Resolution, 51 (6): 848-871.

Licklider, Roy. 1995. 'The consequences of negotiated settlements in civil wars, 19451993.' American Political Science Review, 89 (3): 681-690.

Long, J. Scott and Jeremy Freese. 2003. Regression Models for Categorical Dependent Variables using Stata. College Station, Tex.: Stata Press.

Marinov, Nikolay. 2005. 'Do economic sanctions destabilize country leaders?' American Journal of Political Science, 49 (3): 564-576. 
Mason, T. David and Patrick J. Fett. 1996. 'How civil wars end: a rational choice approach.' Journal of Conflict Resolution, 40 (4): 546-568.

Mason, T. David, Joseph P. Weingarten, and Patrick J. Fett. 1999. 'Win, lose, or draw: predicting the outcome of civil wars.' Political Research Quarterly, 52 (2): 239-268.

McGillivray, Fiona and Allan C. Stam. 2004. 'Political institutions, coercive diplomacy, and the duration of economic sanctions.' Journal of Conflict Resolution, 48 (2): 154172.

Montalvo, Jose G. and Marta Reynal-Querol. 2007. 'Ethnic Polarization and the Duration of Civil Wars.' World Bank Policy Research Working Paper 4192.

Morgan, T. Clifton, Valentin Krustev and Navin A. Bapat. 2006. Threat and Imposition of Sanctions (TIES) Data user's manual. Case level data. University of North Carolina. http://www.unc.edu/ bapat/TIES.htm

Nooruddin, Irfan. 2002. 'Modeling selection bias in studies of sanctions efficacy.' International Interactions, 28: 59-75.

Nurnberger, Ralph. 2003. 'Why sanctions (almost) never work.' The International Economy, 17 (4): 71-72.

Pape, Robert A. 1997. 'Why economic sanctions do not work.' International Security, 22 (2): $90-136$.

Pape, Robert A. 1998. 'Why economic sanctions still do not work.' International Security, 23 (1): 66-77.

Regan, Patrick M. 2000. Users' manual for Pat Regan's data on interventions in civil conflicts. Binghamton, NY: Binghamton University.

Regan, Patrick M. 2002. 'Third-party interventions and the duration of intrastate conflicts.' Journal of Conflict Resolution, 46 (1): 55-73.

Rennack, Dianne E. and Robert D. Shuey. 1998. Economic Sanctions to Achieve U.S. Foreign Policy Goals: Discussion and Guide to Current Law. Washington: Congressional Research Service, Library of Congress.

Ross, Michael L. 2004. 'What do we know about natural resources and civil war?' Journal of Peace Research, 41 (3): 337-356.

Strandow, Daniel. 2006. 'Sanctions and civil war. Targeted measures for conflict resolution.' Uppsala: Department of Peace and Conflict Research, Uppsala University.

Thyne, Clayton L. 2006. 'Cheap signals with costly consequences. The effect of interstate relations on civil war.' Journal of Conflict Resolution, 50 (6): 937-961. 
Tierney, Dominic. 2005. 'Irrelevant or malevolent? UN arms embargoes in civil wars.' Review of International Studies, 31: 645-664.

Tostensen, Arne and Beate Bull. 2002. 'Are smart sanctions feasible?' World Politics, 54 (3): 373-403.

Tsebelis, George. 1990. 'Are sanctions effective? A game-theoretic analysis.' Journal of Conflict Resolution, 34 (1): 3-28.

Wallensteen, Peter, Mikael Eriksson, and Daniel Strandow. 2006. 'Sanctions for Conflict Prevention and Peace Building.' Uppsala: Department of Peace and Conflict Research, Uppsala University.

Walter, Barbara F. 1997. 'The critical barrier to civil war settlement.' International Organization, 51 (3): 335-364.

Walter, Barbara F. 2002. Committing to Peace. Princeton, NJ: Princeton University Press. 